\title{
金属材料の力学的挙動に及济す静水圧の影響*
}

\author{
西 原 正夫** 田中吉之助*** 西 原 守**** 村 松 隆 男**
}

\section{Effect of Hydrostatic Pressure on Mechanical Behaviour of Metallic Materials}

by

Masao Nishimara, Kichinosuke TANAKA,

(Faculty of Engineering, Doshisha University) (Faculty of Engineering, Kyoto University)

Mamoru NishiHARA and Takao Muramatsu

(Kobe Steel Works) (Faculty of Engineering, Doshisha University)

For the study of the effect of hydrostatic pressure on mechanical behaviour of metals and alloys, a tri-axial testing machine was designed and constructed. The machine was designed to carry out tension and compression testing under the confining pressure up to $5000 \mathrm{~kg} / \mathrm{cm}^{2}$ at room temperature.

Tension tests on Zinc, Aluminium, Titanium, Zirconium and $\mathrm{Mg}-\mathrm{Al}$ Alloy were made under confining pressure.

The effects of hydrostatic pressure on ductility, for example, elongation and reduction in area were observed.

(Received Oct. 7, 1963)

\section{1 粕言}

静水正が材料の力学的挙動におよはすす影習について は，古くから多くの人々によって研究されている。高 静水圧下の実験は金属材料についても最近再び行なる れるようになった。

静水圧は金属材料については，従来，降伏条件に第 一近似として影響を及ばさないとして，多くの問題が 扱われ，乙れを裏付ける実験事実る P.W. Bridgman そのほかにより示されている. てれに反して，S.I. Ratner は，静水压が応力とひずみの関係にかなり影 響を字えるとと家実験的に示しており，また H.L1.D. Pugh らも各種の金属材料について静水芐下で引張り およびねじり試験を行なっているが，その結果は必ず しも Bridgman の結論とは一致していない.

実際に各種の金属材料の力学挙動に及沽す静水王の 影響を検討するために，一種の三軸応力試験装置を訊 作した。乙れは最高 $5000 \mathrm{~kg} / \mathrm{cm}^{2}$ までの静水压下で 引張試験および正縮試験を行ない得るものである，本 報告は試験装置, 実験方法拉よび引張試験結果の概要 である。

\section{2 実験装置および実験方法}

* 原稿受付 昭和38年10月 7 日, 日本林料試鈋協会第11期(昭37. 5.8 ), 日本材料学会第 12 期 (昭38.5.11) 譜演会に 七㒛觉

** 正員 同志社大学工学部

**** 正員 京都大学工学部

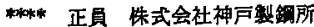

昭和39年 1 月
三軸応力試験の方法および試験機には種々あるが， 本研究はある応力状態に高静水正(応力の等方成分)を 重ね合せた場合に，材料の力学的挙動にどのような変 化を与えるかを明らかにするために，一種の三軸応力 試験装置を諮作し，各種の金属材料について実験を行 なったむのである。

試験装置は設計製作の容易なとと，および試験操作 の安全なとと等のため R.O. Breadthauerらの用いた 方法に変更改良を加えたるのを試作した，乙の試験装 置は一種の増王機であって，吐出压の比較的低いポン プによって試驗片を装着した 高王シリンダ内に 5000 $\mathrm{kg} / \mathrm{cm}^{2}$ までの高静水圧を 発生させるととができるも のである.とのようにして，高厈シリンダ内で等方的 に圧縮された状態で，さらに試験片軸方向に荷重を加 えると $\sigma_{1}>\sigma_{2}=\sigma_{3}$ (引張試験)，または $\sigma_{3}<\sigma_{2}=\sigma_{1}$ (圧 樎試験）の応力状態が実現される．その構造の概略は Fig. 1 に示したとおりであり，試験片 S に高静水王 を与えるには，低圧シリンダ $\mathrm{C}_{2}$ に压樎空気により作 動する油ポンプによって一定圧の油を送り込み，ピス トン $\mathrm{P}_{2}$ を高王シリンダ $\mathrm{C}_{1}$ 内に押し込む。・ピストン $\mathrm{P}_{2}$ の低圧側および 高王側の面積比にしたがって増压 されるが，本装置においては増王比は1：16である。 高王シリンダ内の油王は高王シリンダに取り付けたブ ルドン管生力計によって計測される，高压シリンダ $\mathrm{C}_{1}$ には，同じ直径のピストン $\mathrm{P}_{1}$ と $\mathrm{P}_{2}$ があり，乙れ らは环板 $\mathrm{L}_{1}$ ，連結棒 $\mathrm{R}_{1}$ および圧板 $\mathrm{L}_{3}$ によって連結 
されているため, ピストン $\mathrm{P}_{2}{ }^{\mathrm{r}}$ の压入に応じた高静水 正を発生させるととになる。

次に，てのような高静水压が加えられた状態で，本 装置を万能試験機で医縮すれば，王板 $\mathrm{L}_{1}$ が下りピス トン $\mathrm{P}_{1}$ が押し下げられて試験片 $\mathrm{S}$ に軸方向の引張り または压縮荷重が加えられる，ピストン $\mathrm{P}_{1}$ が环入さ れただけピストン $\mathrm{P}_{2}$ は拥し出されるととにより，試
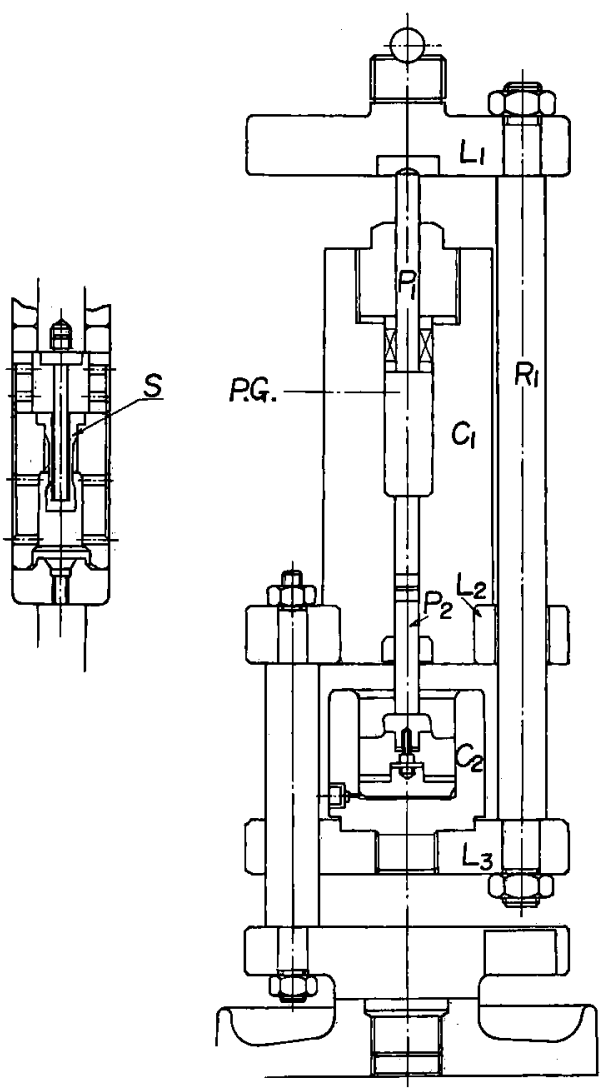

Fig. 1 Testing appratus
験片の体積変化および高压シリンダの变形を無視すれ ば，静水压は一定之考光られる。

引張試驗を行なう場合の応力状態の変化は，高静水 王が加えられた状態では三軸等方圧縮 $\sigma_{1}=\sigma_{2}=\sigma_{3}$ （静 水压）であるが，粙方向の荷重を加えていくと，試験 片の軸方向の王縮応力は次第に減少して 0 となり，次 いで弓張応力を生ずるようになる.なお，計力機の指 示する荷重は軸方向の応力に対応した荷重をそのまま 与えるものではなく，主応力差に相当した荷重に，ピ ストンと高压シリンダ間の摩擦力を加えたものである。 上に述べた摩擦力は静水圧の関数であるが，ある静水 压の下で必ずしも一定ではない，ての摩擦力は試験片 を装着しないで実験を行なうてとによって計測して の檤を計力機に指示された荷重值より差し引いた。

ひずみの計測はピストン $\mathrm{P}_{1}$ の変位をダイヤルゲー ジで計測し，同時に差動変王器式伸び計による自記記 録む行なった。 また，正力媒体には少なくとも5000 $\mathrm{kg} / \mathrm{cm}^{2}$ までは凍結しないホワイトスピンドル油を用 いた.

\section{3 試験材および試験片形状寸法}

試験に供した材料は亜鉛(鋳造)，アルミニウム，チ タニウム，ジルコニウム， Mg-Al 合金の 5 種類の金 属および合金を用い,とれらの化学成分を Table Iに

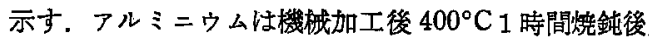
その他の材料は機械加工のまま実鈳に供した，試験片 の形状寸法は Fig. 2 に示すような一端を閉じた中空 状試験片で，試験片底部を押すてとによって軸方向の 荷重が加えられ得るものである，中空状試険片の内外 に同一の静水王を受ける場合には，その応力状態はむ まり厚肉でない限り中実試驗片を試験する場合之同じ と考えるととができる。

\section{4 実験結果と考察}

種々の静水压下で引張試験を行なった後の訊験片を

Table I Chemical composition of materials tested $(\%)$

\begin{tabular}{|c|c|c|c|c|c|c|c|c|c|}
\hline Material & $\mathbf{H}_{2}$ & $\mathrm{O}_{2}$ & $\mathbf{N}_{\mathbf{2}}$ & & & $\mathrm{C}$ & & $\mathrm{Zr}$ & \\
\hline Zirconium & 0.0043 & 0.051 & 0.002 & 0.005 & 0.083 & 0.008 & 0.40 & Balance & \\
\hline Titanium & $\begin{array}{c}\mathrm{H}_{3} \\
0.015\end{array}$ & $\begin{array}{c}\mathrm{O}_{2} \\
0.078\end{array}$ & $\begin{array}{c}\mathrm{N}_{2} \\
0.035\end{array}$ & $\begin{array}{c}\mathrm{Si} \\
0.017\end{array}$ & $\begin{array}{c}\mathrm{Fe} \\
0.050\end{array}$ & $\begin{array}{c}C \\
0.01\end{array}$ & $\begin{array}{c}T i \\
\text { Ballance }\end{array}$ & & \\
\hline Aluminium & $\begin{array}{c}\mathrm{Cu} \\
1.11\end{array}$ & $\begin{array}{c}\mathrm{Mg} \\
0.24\end{array}$ & $\begin{array}{l}\mathrm{Mn} \\
0.14\end{array}$ & $\begin{array}{r}\mathrm{Fe} \\
0.55\end{array}$ & $\begin{array}{c}\mathrm{Si} \\
0.28\end{array}$ & $\begin{array}{r}\mathrm{Zn} \\
0.16\end{array}$ & $\begin{array}{l}\mathrm{Cr} \\
0.02\end{array}$ & $\begin{array}{c}\mathrm{Ti} \\
0.01\end{array}$ & $\begin{array}{c}\text { Al } \\
\text { Baiance }\end{array}$ \\
\hline Zinc & $\begin{array}{c}\text { Pb } \\
0.0008\end{array}$ & $\begin{array}{c}\mathrm{Cd} \\
0.098\end{array}$ & $\begin{array}{c}\mathrm{Fe} \\
0.001\end{array}$ & $\begin{array}{c}5 n \\
<0.001\end{array}$ & $\begin{array}{c}Z_{n} \\
\text { Balance }\end{array}$ & & & & , \\
\hline $\begin{array}{l}\text { Mg-Al } \\
\text { Alloy }\end{array}$ & $\begin{array}{r}\text { AI } \\
0.87\end{array}$ & $\begin{array}{c}\mathrm{Be} \\
0.008\end{array}$ & $\begin{array}{c}\mathrm{Si} \\
0.003\end{array}$ & $\begin{array}{c}\mathrm{Fe} \\
0.006\end{array}$ & $\begin{array}{c}\mathrm{Cu} \\
0.0003\end{array}$ & $\begin{array}{c}\mathbf{M g} \\
\text { Balance }\end{array}$ & & & \\
\hline
\end{tabular}


Fig. 3に示す. てれより，静水压兮変形の特性および 状態に著しく影锌を拉よばす材料と，そうでないるの とがあるように思われる。

亜鋥、アルミニウム，チタニウム、ジルコニゥム， $\mathrm{Mg}-\mathrm{Al}$ 合金の弓張試験結果を応力一ひずみ線図として それぞれ Figs. 4，5，6，7，8 亿示す. 縱軸を主応力差 $\sigma_{1}-\sigma_{3}\left(\mathrm{~kg} / \mathrm{mm}^{2}\right)$, 横軸をひずみ $\varepsilon(\%) て ゙$ 表わしたも のである. 静水印の增加に伴う亜鉛の伸びの增大は著 しいが，フルミニウムの伸びは静水匤の影響をあまり 受けないようであり，てのような傾向はチタニウム， ジルニンム， Mg-Al 合金においても認められる.

重鉿およびアルミニウムの試験片のあるむのには， フォトグレイティングをほどてして，試験片軸方向の 伸びおよびその分布を測定し, 他方, 压力容器の外㑡 でダイヤルゲーシによって測定した伸びの値との比較 を行なった．Fig. 9 は静水圧と伸びの関係を示した むのである. ての図よりフォトグレイティング法によ り求めた破断伸びと，間接的にダイヤルダージで測定 した伸びの值は汪は一致しており，とのてとは容器の 外側で間接的にダイヤルゲージによって伸びの測定を 行なってむよいととを示している. また同図より，フ ルミニゥムの破断伸びは 19〜23\%，一般伸びは 10〜 $13 \%$ 範囲にあり，前者は後者の約 2 倍であるが，い ずれる静水圧による变化はあまり認められない，亜鉛 については，常王における一般伸びは1\%であるのに 対して, $1800 \mathrm{~kg} / \mathrm{cm}^{2}$ の下では $5 \%$ と明らかに増大し ているが，乙の場合の破断伸びは 30〜 40\%で，一般 伸びに比較すると著しく大であり，破断伸びの大部分 は局部的な伸びによるものである。

一般の三軸応力状態における応力解析を行なうには， 破断伸びおよびその内の一般伸びが，静水正によって どのように影警されるかを明らかにしなければならな いが、実験結果によると，伸びの大部分は局部的な伸び によるものであって，変形は一様ではない，てのてと は, 乙の種の実験によって得られた主応力差 $\left(\sigma_{1}-\sigma_{3}\right)$ と軸方向のひずみ $(\varepsilon)$ との関係曲線を用いて一般の応 力解析を行なうのに，大きな制限があるととを意味し ている.

静水正下の材料の変形能を研究するには絞りもまた 重要である. Fig. 10 は静水压と絞りの関係を示した

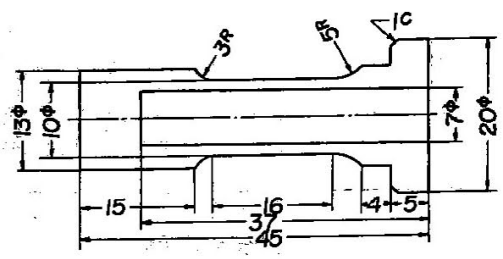

Fig. 2 Specimen for tension test

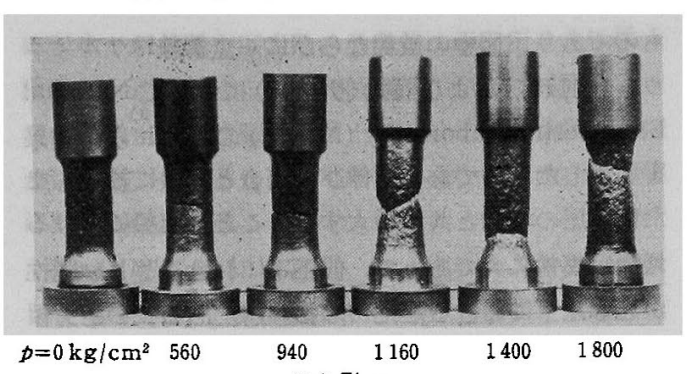

(a) Ziric

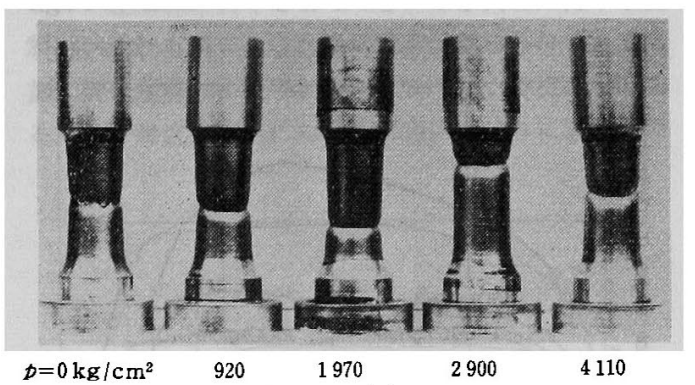

(b) Aluminium

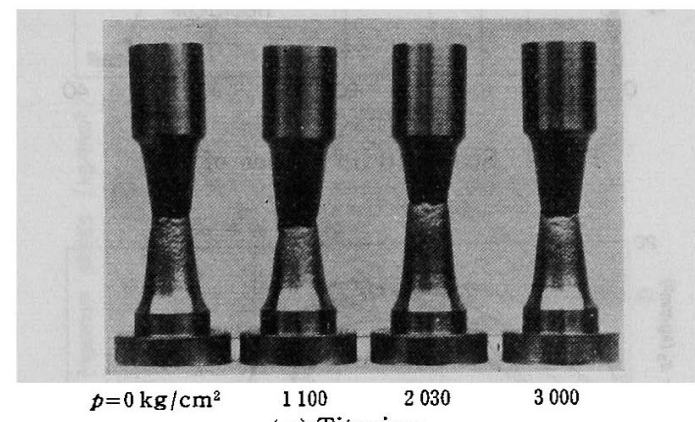

(c) Titanium
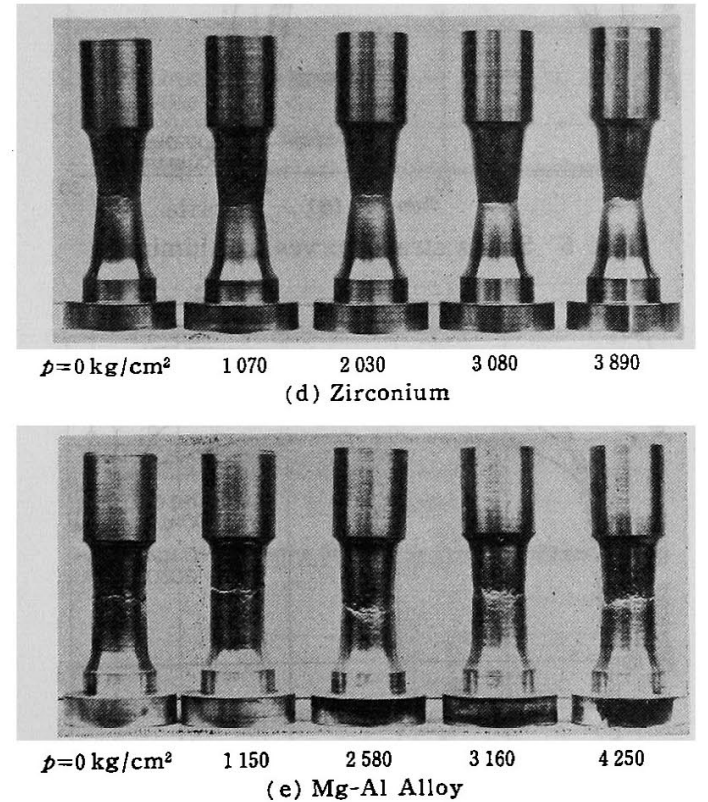

Fig. 3 Tested specimens under various confining pressures 
ものであり，因中の破線ならびに一点鎖線はアルミ ウム(引抜材) および亜鉛 (引拔材) について National Engineering Laboratory (N.E.L) の Pugh らの結果 を引用したものである，伸びの場合と同様に絞りもま た静水圧の増加と共に增大する。ととに亜鉛に拉ける 増加は異常に大であって，低压下におけり著しい脆性 から高王下に拈ける延性への転移は，ある狭い王力領 域に打いて急激に起てる.てのととは，試験材の化学 成分や製法が異なるにもかかからず N.E.L. の Pugh

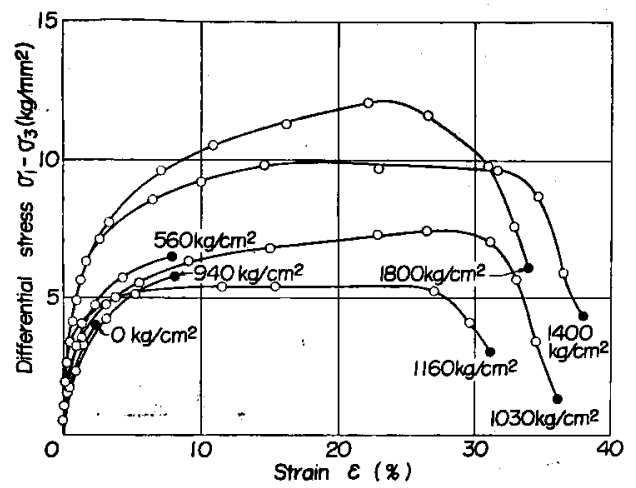

Fig. 4 Stress strain curves of Zinc

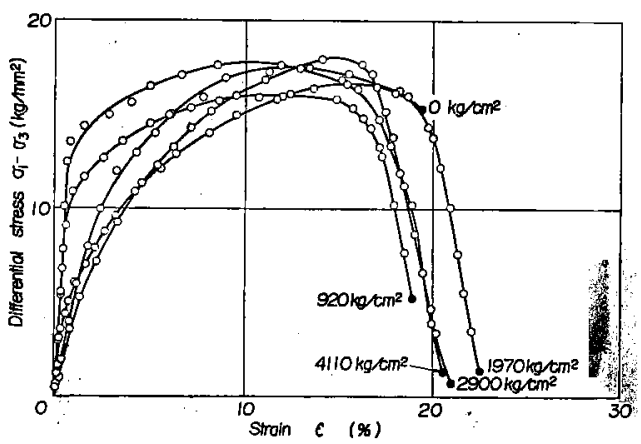

Fig. 5 Stress strain curves of Aluminum

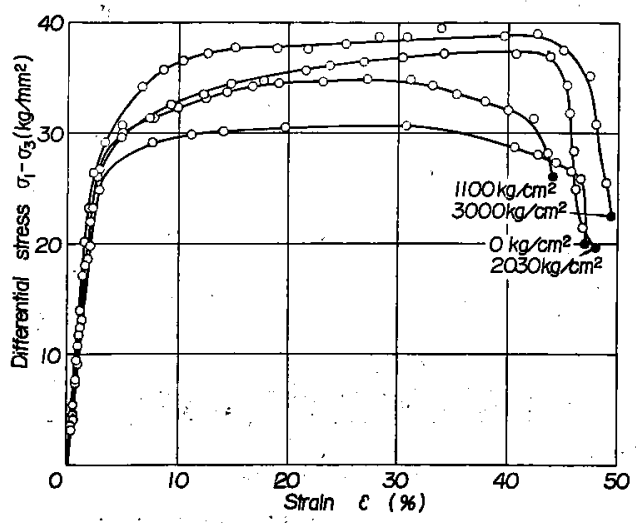

Fig. 6 Stress strain curves of Titanium
らが得た実験結果とよく一致している，ての転移压力 は䄪 $1000 \mathrm{~kg} / \mathrm{cm}^{2}$ である. これに反して，常压にお いてもかなり延性の高いァルミニウムについては，校 りの増加は亚鉛ほど著しくないが，粎 $3000 \mathrm{~kg} / \mathrm{cm}^{2}$ 以 上の静水正においてはほとんど $100 \%$ 達する。 また チタニゥム，ジルコニウムおよび Mg-Al 合金の絞り の增加は比較的小さい. Fig. 11 は試殹後の試験片の 縱断面を示したものであるが，重鉿の場合，常王の時 にはほとんど変形を伴わない脆性破壊であるが, 1030 $\mathrm{kg} / \mathrm{cm}^{2}$ では大きな変形をし，その破断面は刃状を呈

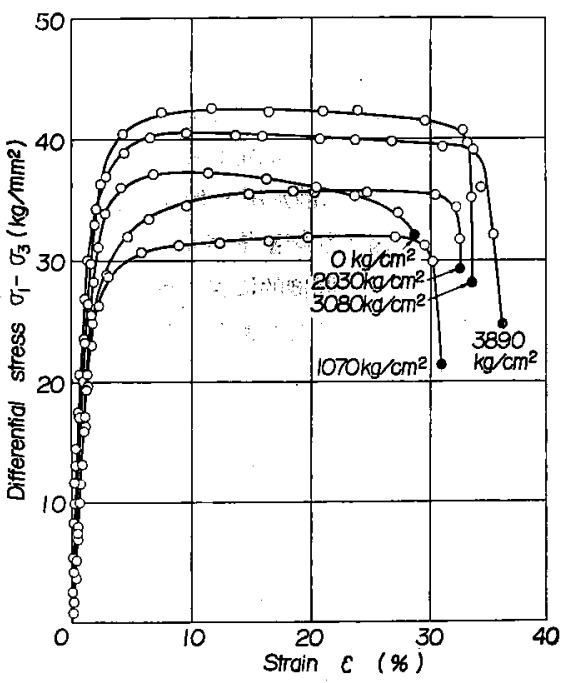

Fig. 7 Stress strain curves of Zicronium

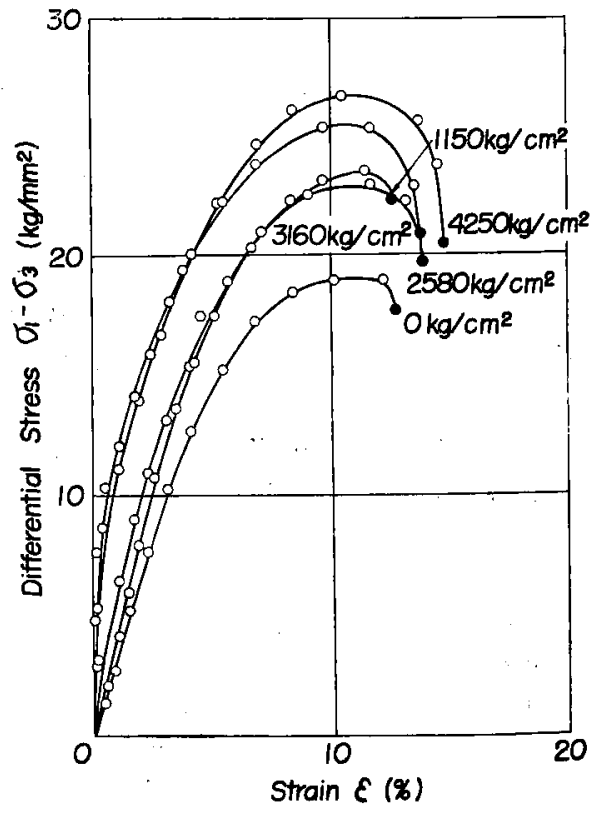

Fig. 8 Stress strain curves of Mg-Al Alloy 
し，著しく大きい絞り定示している．またアルミニウ ムの局部伸びおよび絞りがきわめて大きいてとも明ら かである、チタニウムとシルコニウムは異常な変形特 性を有している、すなわち，Fig. 11 でも認められる ように，伸びの增大につれて試験片中央部は内外径共 に縮小し，全体として絞られる．乙の現象は常压下の 試験においても認められ，両材は，Fig. 2 に示す試 駼片の内径寸法を $8 \mathrm{~mm}^{\phi}$ に交更して実駼を行なった.

応力ーひずみ曲線から求めた主応力差 $\left(\sigma_{1}-\sigma_{3}\right)$ およ び軸応力 $\left(\sigma_{1}\right)$ の最大值の静水圧による変化を Fig. 12

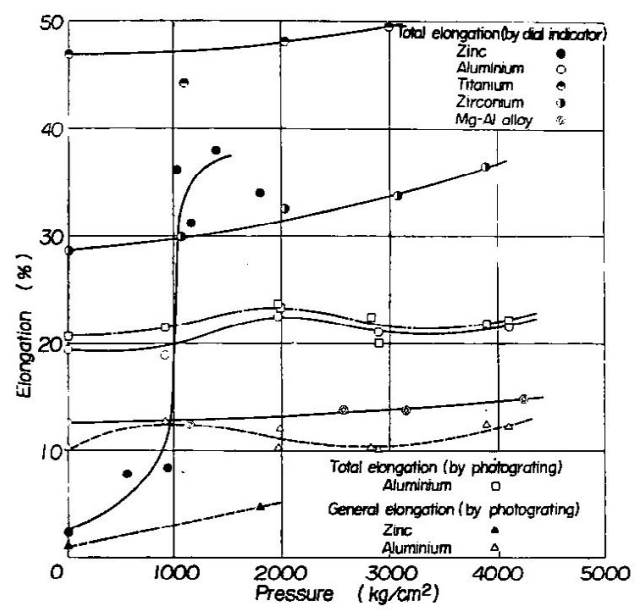

Fig. 9 Effect of pressure on elongation at fracture

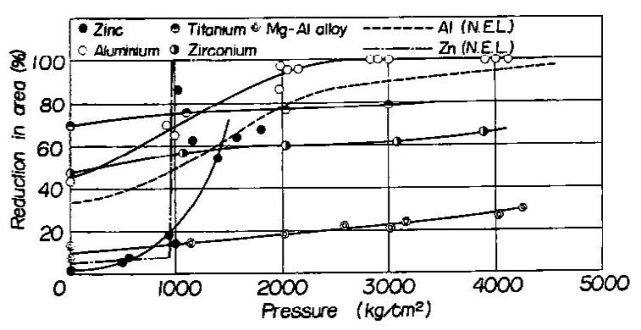

Fig. 10 Effect of pressure on reduction in area at fracture

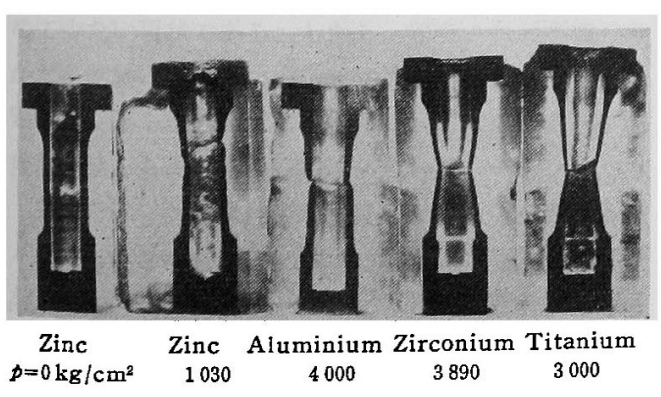

Fig. 11 Longitudinal section of tested specimens
に示す. 一般に主店力差の最大值恃静水压と共に增大 するが，逆に軸応力の最大值は隇少する，材料によっ て異なるが，ある静水压以上においては，軸応力 $\left(\sigma_{1}\right)$ が引張応力となるととなく縮応力の領域内で最大值 に達し破断に至る.

Figs. 13，14，15 に西鈆，アルミニウムおよびチタ ニウムのモールの応力円を示す，乙れらは最大応力お よび種々のひずみ量に対するモールの応力円を描き， てれに包絡線を引いたものである. 本実験に供した材 料はいずれも明りょうな降代現象が認められず，また 加工硬化曲線は $\mathrm{Mg}-\mathrm{AI}$ 合金を除けば，注ぼ水平であ るため，降代点応力に対する応力月の代りに最大応力

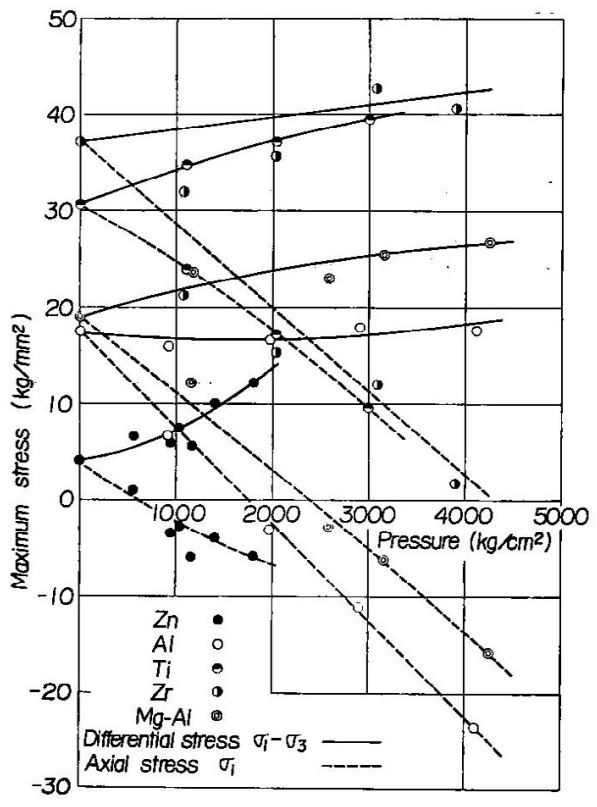

Fig. 12 Effect of pressure on maximum stress

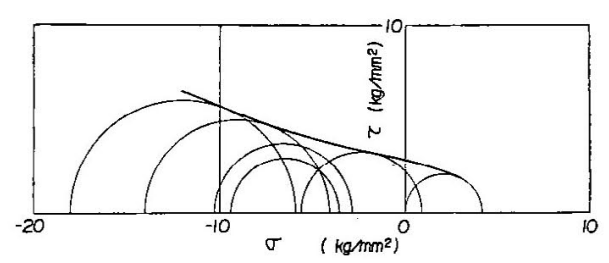

Fig. 13 Mohr's diagram for Zinc

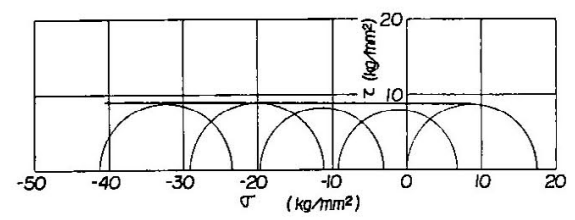

Fig. 14 Mohr's diagram for Aluminium 
に対するむのを措いた．乙れらの包絡線は亜鉛の場合 を例外とすれば， $\sigma$ 軸にほ隹水平ないしは多少の傾斜 をむっている。

\section{5 結 言}

材料の力学的挙動におよぼす静水正の影響を明らか にするために，一種の三軸応力試驗装置を試作した。 本装置は常温に批いて，5000 $\mathrm{kg} / \mathrm{cm}^{2}$ までの静水圧の 下で引張試験および式縮試駼を行ない得るものである。

静水匠が 0 4 $250 \mathrm{~kg} / \mathrm{cm}^{2}$ の下で带鉿, アルミ二ウ ム, チタニウム, ジルコニウム, Mg-Al 合金の引張

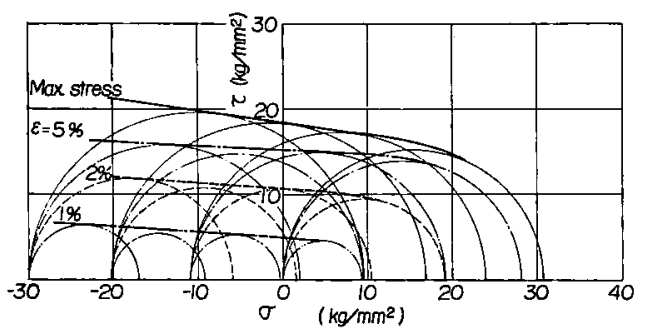

Fig. 15 Mohr's diagram for Titanium
試験を行ない，金属材料の力学的挙動，たとえば破断 伸び，校り等の延性は静水压の增加之共に增大し，伸 びの增加の大部分は局部伸びであるてとが認められた， ことに亜鉛については，静水压の影瑤は異常に大きく， 約 $1000 \mathrm{~kg} / \mathrm{cm}^{2}$ 定境として，脆性から延性への著し い転移を示す。

なお，本装置を用いて数種の岩石の厌縮試験も行な ったが，從来報告されているものとほ结同様な結果を 得るととができた。

目下, 高圧容器内で試騟片に加えられる荷重および 変形を直接測定するととを試みているので，てれらに ついては結果学得た上で報告したいと思う。

\section{参考 文 献}

1) Bridgman, P.W., J. Appl. Phys.. 24, 560 (1953).

2) Ratner, S.I., Z. Tekh. Fiz. USSR, 19, 408 (1949).

3) Pugh, H.Ll.D., and D. Green, N.E.L. Plasticity Report No, 128 (1956).

4) Breadthauer, R.O., Trans. ASME, 79, 695 (1957). 